\title{
Play in Melbourne City
}

\author{
Zan (Suzannah) Griffith \\ RMIT University, Australia \\ zangriffith@me.com
}

\begin{abstract}
Play in Melbourne City outlines a series of playful incursions in Melbourne, Australia's central city that hopes to act as a reminder of the potential power and influence that individual citizens have in disrupting, creating and recovering public space.

This is a practice-based exploration that uses Melbourne city as its site. Through a series of playful guerrilla theatre style incursions, the artist creates and embodies fictional characters that spontaneously appear throughout the city. Notions of the carnivalesque are harnessed through the use of masks, costumes and puppetry. Each character investigates and responds to a specific issue of spatial politics within the city, with the works importantly sitting outside of the scheduled template of gallery exhibitions and festivals.

For the conceptual framework, the artist draws on Henri Lefebvre's ideas of the production of space and Chantal Mouffe's 'agonistic' model of public space.
\end{abstract}

Keywords: public space, protest, play, carnivalesque, citizen

To cite this article:

Griffith, S. (2020) Play in Melbourne City, The Journal of Public Space, 5(4), 353-367, DOI 10.3289I/jps.v5i4.1420

This article has been reviewed by the Editors and accepted for publication in The Journal of Public Space.

This work is licensed under a Creative Commons Attribution - Non Commercial 4.0 International License https://creativecommons.org/licenses/by-nc/4.0/ 


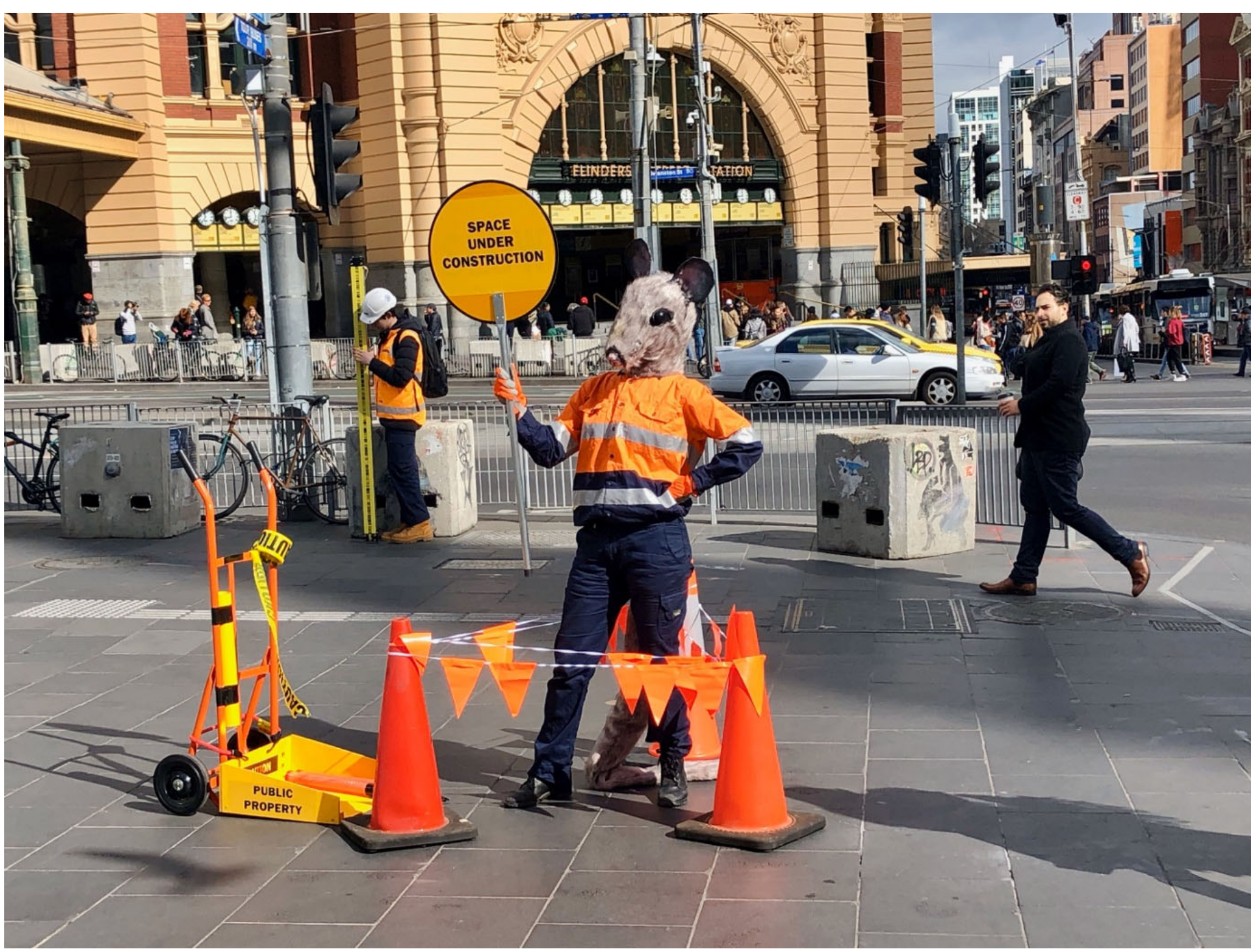

Figure I. The Envoy of Mischief. Swanston St, Melbourne, 2018. Photo by Jeremy Griffith.

In this portfolio I briefly outline my art practice, the theoretical frameworks that I have drawn on in my exploration of public city space, and the works that were created over the course of my Master of Arts (Art in Public Space) at RMIT University, Melbourne, Australia, as I posit the notion that one citizen has the potential to disrupt, create and recover public city space. In Play in Melbourne City I am making a performative 'claim' to space through a series of playful and humorous incursions which attempt to resist and protest representations of space and ultimately shift the public imaginary. The incursions endeavour to harness the power of the carnivalesque and to act as a reminder that nascent within the lone citizen lies the capacity to disrupt, create and recover public city space.

I describe my art practice as a lone rogue carnivalesque protest employing masks, costumes and occasionally puppetry to generate this carnivalesque and playful space. My 
interpretation of the carnivalesque can be described as the creation of a space outside of the everyday milieu. A liminal space where there is a deconstruction and upending of conventions and the status quo. Bakhtin (1984, p. 7), explains that it is through humour and laughter that 'a second world and a second life outside of officialdom' is built. He proposed the carnival as the moment when the dominant power structures could be subverted. For example, kings become fools and fools become kings, producing a window into a topsy turvey world, created through humour, laughter and chaos. In this space of the spectacle there is a revolutionary power in that it not only acts out against the hegemonic discourse but confirms the existence of another world outside of the 'official' one (Bakhtin 1984).

Potential opposition to this idea has been that the very carnival itself acts as a tool for the dominant power structures to suppress the people. The carnival becomes a mechanism of sedation and relief for the masses so that once the carnival finishes, they can then peacefully return to the status quo. With this in mind, I purpose the fanciful idea that in my art practice, the characters I embody are carnival characters gone rogue... lone characters who have left the carnival to reappear unexpectedly, each time reinvented, so as to extend and fuel the continued life of the carnival within the everyday. The invention of different and absurd characters in my practice plays into this idea.

As an artist I hope to harness these powers of the carnivalesque where anything is possible. I create fictional characters that I embody and insert into public city space in a guerrilla theatre style that attempt to explore some of the spatial politics of Melbourne city. I am calling these moments 'incursions'. The Cambridge definition of incursion is 'a sudden attack on or act of going into a place, especially across a border.'(Cambridge 2020). The work relies on transgressing all kinds of borders of public space with the intention to make them visible.

The works that I outline here, all intentionally sit outside of the scheduled template of galleries, museums and festivals. This allows the incursions to be encountered by chance in a setting that is not associated with art. The audience is both the public on the street and the public on social media sites where I post the video documentation of the performances.

For the public on the street, the work is transitory and may only be experienced for a moment as they pass it, or stop to photograph it. At this first level, the work aims to disrupt the space through a sense of the absurd. For the public on social media sites more of the fictional narrative can be shared.

I am drawn to the idea of the lone protest. There is a power in the individual protestor as it displays a vulnerability that does not have the moral authority of a group. It presents to the public an individual clashing with the dominant Goliath powers...the underdog scenario. It hopes to act as a reminder of the agency and power of the individual citizen.

The site of my investigations has been the city of Melbourne. I consider the city as my primary site of protest as it is where the major economic, cultural and political stake holders are based. It is also a site that the whole population of Melbourne has access to. All roads, trains and trams lead into the city, and all major sporting and cultural events mostly take place in or around the city. These factors make it the ideal site for protest. Sassen (2017, Pp. 124-125) describes the city as 'a complex but incomplete system', where there "lies the possibility for those without power to be able to assert, "We are 
here," and "This is our city". Essentially, the ordinary citizen can have a voice and be heard in the city. My incursions also present themselves to the City to be seen and heard as a way to reclaim space.

My practice draws on Henri Lefebvre's text, The Production of Space. The French Marxist philosopher and sociologist wrote of space as a concept that is not fixed, but is continually being produced (Lefebvre 199I). He was a revolutionist and understood that space is power and the role it plays in the continuation of capitalism. Lefebvre (199I, p.54) wrote that 'A revolution that does not produce a new space has not realized its full potential.'

Lefebvre (199I, p40) outlines three elements that combine to produce space as the 'perceived-conceived-lived triad (in spatial terms: spatial practice, representations of space, representational spaces)'. It is in the 'representational spaces', that Lefebvre suggests there is an opportunity to impact space. This space, 'embracing the loci of passion, of action, of lived situations' is described as 'qualitative, fluid and dynamic' (Lefebvre 1991, p.42). Here lies the potential for revolution. As space is continually being produced by the interplay of these forces, there is the opportunity to resist and momentarily transform the abstract space that is produced through capitalism. So when my characters disrupt the street through incursions into the space, they not only disrupt the pedestrian flow of traffic but the bodily presence is creating space and thereby regaining power. By producing 'representational space' that resists the dominant 'representations of space' (Lefebvre 199I) there sits a power to change that occupation of space. Since we are a predominantly visual culture simply seeing people act in deviating but unharmful ways becomes a means of change.

In relation to the notion of space as a contested site, Mouffe (2007), a Belgium political theorist, offers up an 'agonistic model' of public space. She describes the model as one where, 'public space is the battleground where different hegemonic projects are confronted, without any possibility of final reconciliation.' and 'not conceived as the terrain where consensus can emerge' (Mouffe 2007)

In viewing public space through this political lens, it follows that public space can be seen as a combative space where practices of hegemony and exclusion dominate. The danger in presenting or considering public space as a consensual space is that it camouflages the reality and therefore denies the opportunity for the individual citizen to act and present an alternative. Revealing these forces and foregrounding this 'battleground' (Mouffe 2007) therefore becomes vital.

Indeed, this model also acknowledges the notion of space as a fluid and dynamic one that is constantly being produced (Lefebvre 1991). To view public space as a contested site (Mouffe 2007) and not a fixed space (Lefebvre 199I) foregrounds both the competing forces that are at play within space and the opportunity each of us as individual citizens have in shaping and producing space. My incursions aim to expose these tensions by rupturing the space with the unexpected thereby puncturing the myth that public space has a unified consensus (Mouffe 2007). 


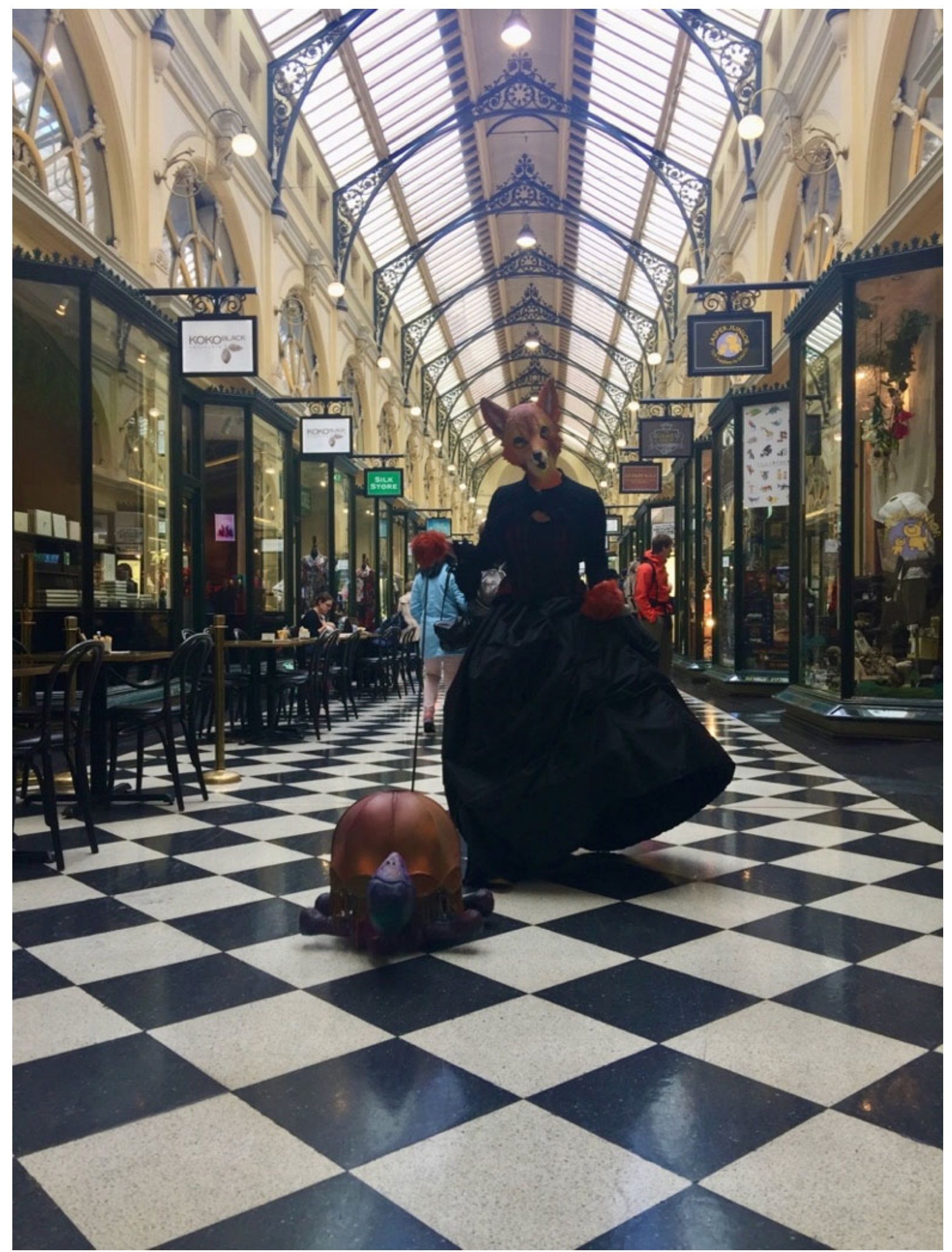

Figure 2. Flaneuse Fox and Croissant the Tortoise. Block Arcade, Melbourne 2017.

Photo by Jeremy Griffith 
Play in Melbourne City

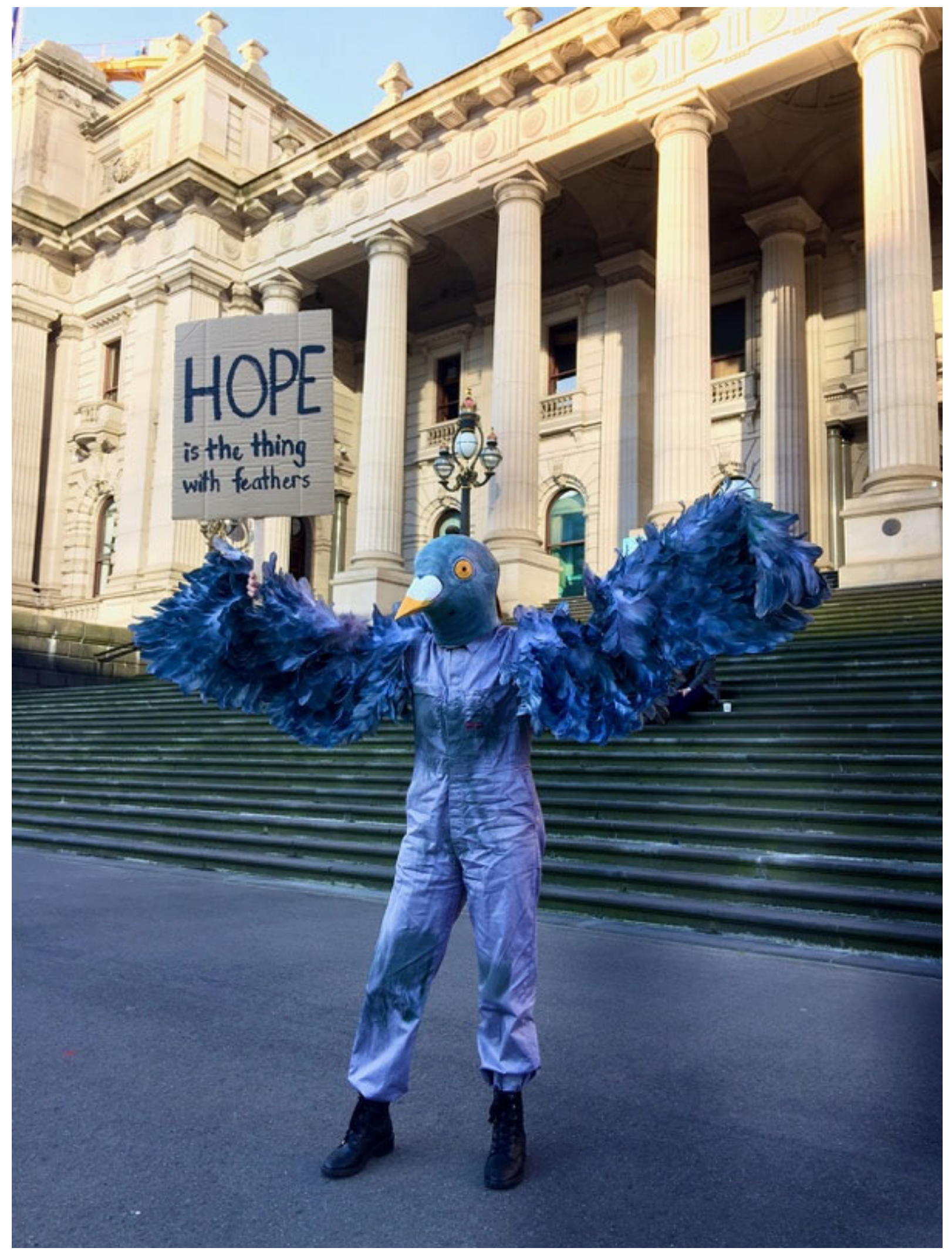

Figure 3. The Protest Pigeon. Victorian State Parliament, 20I8. Photo by Jeremy Griffith 
The Flaneuse Fox and her puppet tortoise, Croissant was my first incursion as part of my Master's project. Flaneuse Fox was a character, playing on Francis Alys's artwork, The Nightwatch. In this work Francis Alys lets loose a fox in the London Portrait Gallery at night and uses the gallery's surveillance cameras to record the fox's movements. In my work the agency has shifted from a fox under surveillance to one doing the watching. Flaneuse Fox was investigating the kinds of spaces women had access to and those from which they were barred in Melbourne's history and exploring what it might mean today to be a female flaneuse in contemporary Melbourne. In this series of incursions, I am making a retrospective claim to public space on behalf of the women who were excluded from public space at the time of modernity. The artwork was comprised of a series of incursions around historic Melbourne sites and formed the footage for a mini $10 \mathrm{~min}$ video that playfully revealed some of the public spaces that women from the past were barred. It looked at the dates of first public toilets for women in the city compared to men, access for women to Australian universities and the right for women to vote. The Protest Pigeon was attempting to represent the everyday citizen and responded to the numerous global and local protests post Trump and the Australian 'yes' vote. With a pigeon mask on, and feathered wings for arms, the protest pigeon held up a protest sign reading 'Hope is the thing with feathers'. As part of a series of incursions at recognised protest sites within Melbourne, I attempted a durational piece at The State Library. I was asked rather forcefully by security to leave the space after about 10 to 15 minutes. I was told it was not public property. Here unintentionally, I am making visible some of those invisible boundaries of public space.

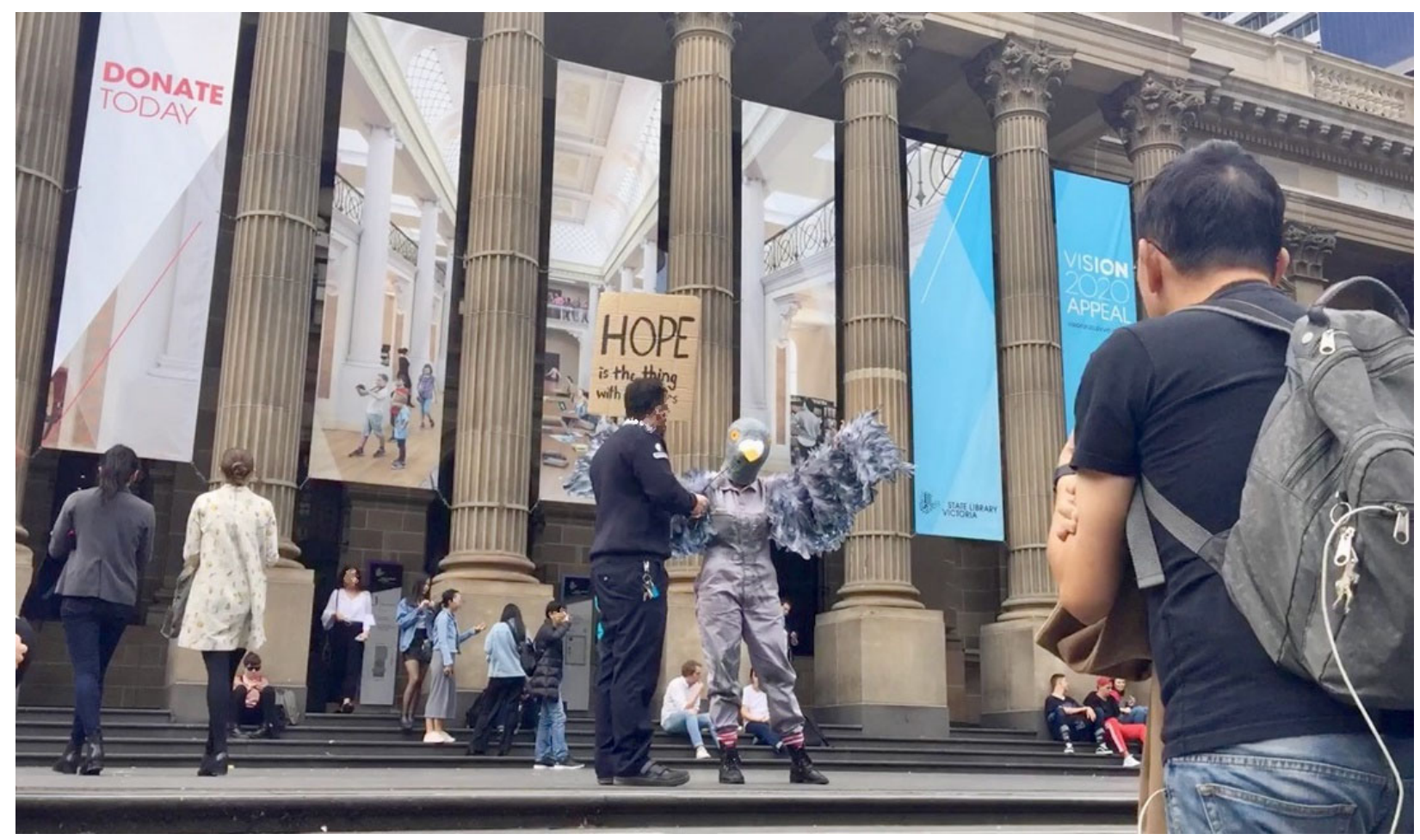

Figure 4. Protest Pigeon. State Library, Melbourne, 2018. Photo by Teddy Griffith.

(face of security guard has been pixelated) 
There is a power in the ridiculousness of asking a pigeon protesting about hope to leave the space. I also propose that by creating protests that don't read as a standard protest, not only may I at times trespass in places others may not, but hopefully the public may be more receptive to the work by using humour to disarm and engage. Here, I have foregrounded the notion of public space as a 'battleground' (Mouffe 2007), as I have revealed in this moment, the space as a contested site. After this experience, I began to think more consciously about how I might expose some of the invisible boundaries of public space.

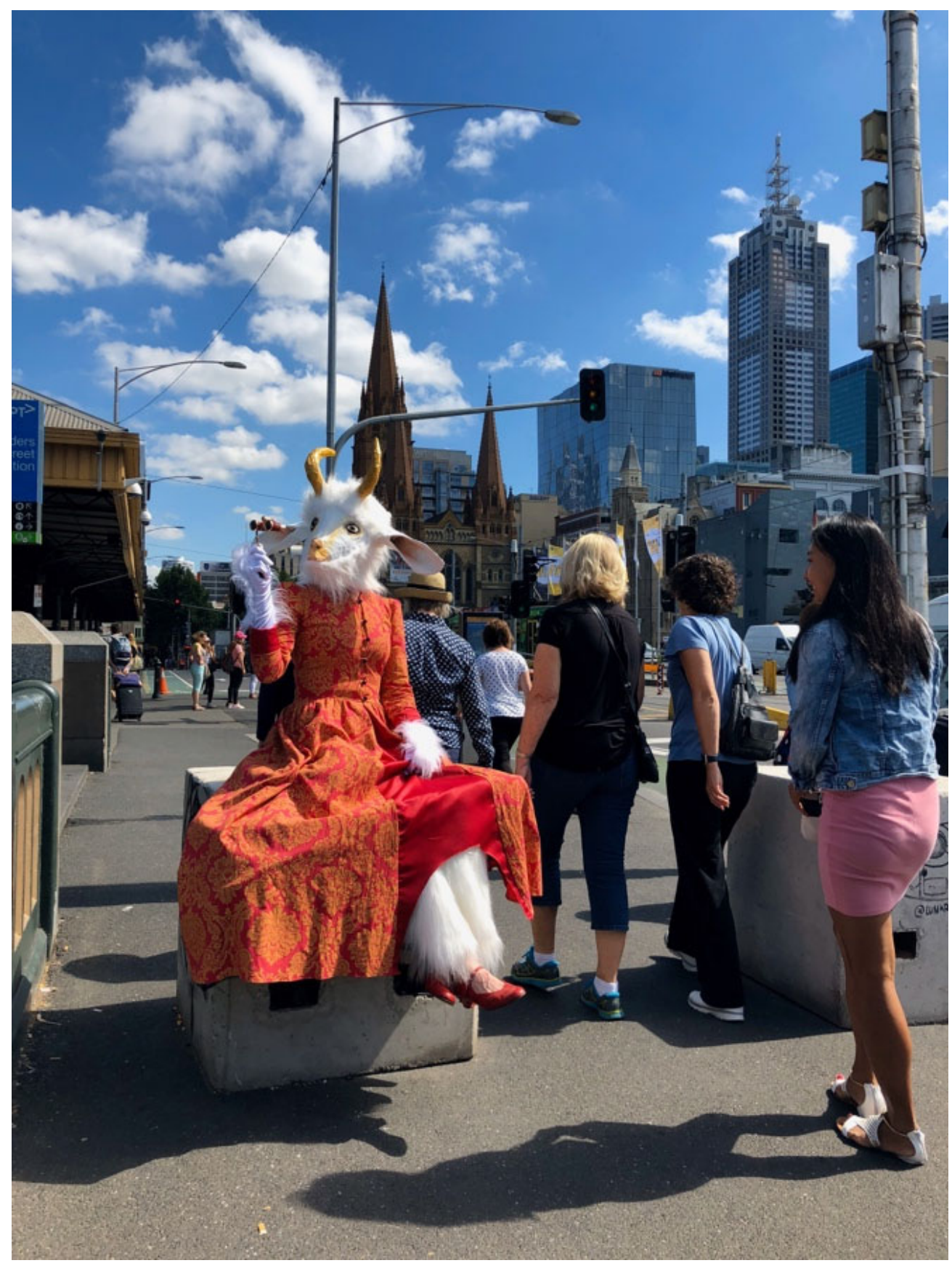

Figure 5. Fairytale Goat. Prince's Bridge, Melbourne 2018. Photo by Jeremy Griffith 
The Fairytale Goat was a response to the new bollards and chicanes that were erected on Princess Bridge around the end of 2017 after the London Bridge terrorist attack of June the $3 \mathrm{rd}$ in 2017. The goat character's costume echoes the colours of the chicanes and as she 'trip, trap, trips' across the bridge she attempts to creates a counter narrative to the fear based one that these new ways of protecting the city evoke.

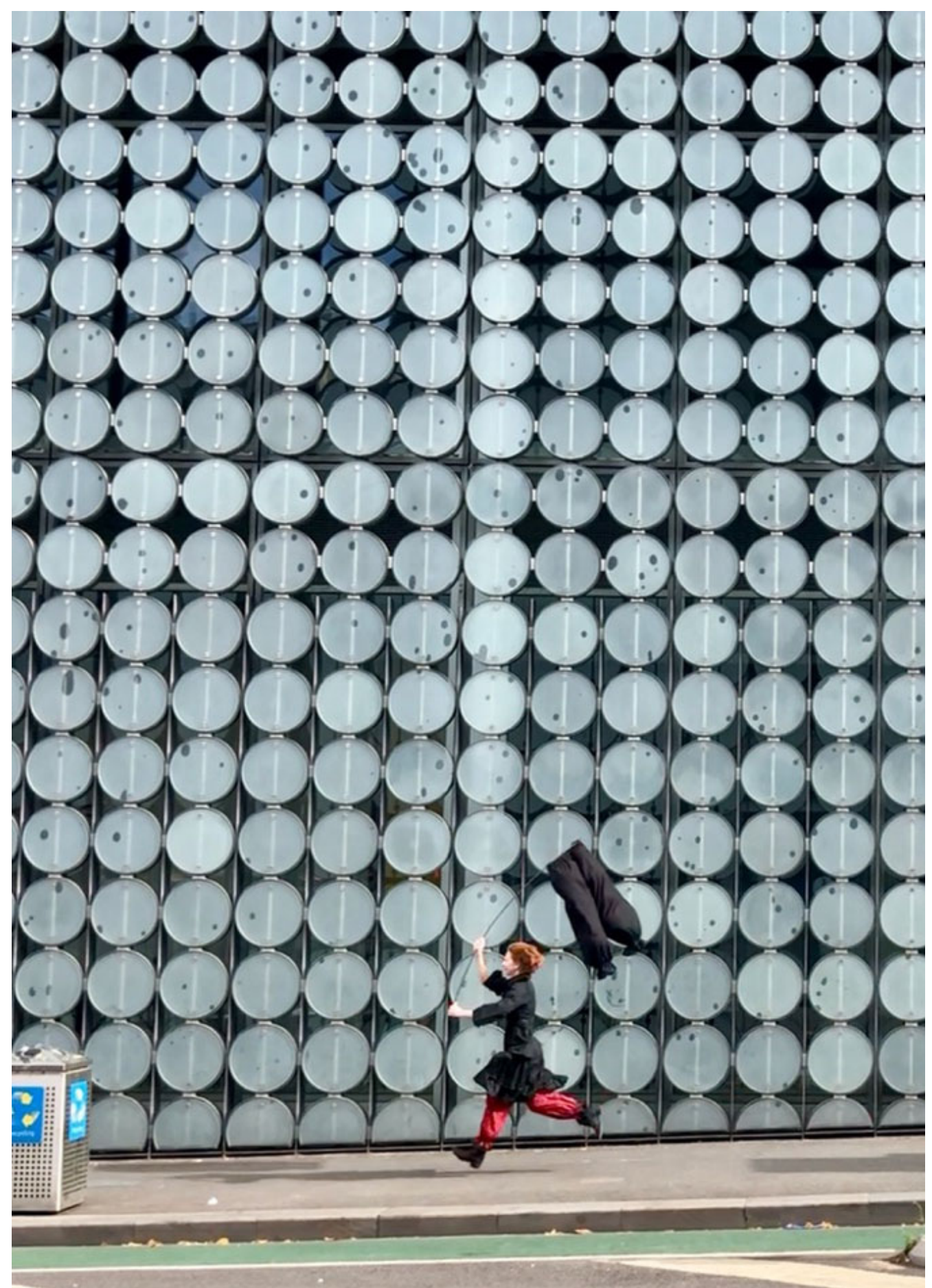

Figure 6. Blooming Fast. Swanston St, Melbourne, 2018. Photo by Teddy Griffith. 
This globalised culture of fear plays into the neoliberal ideology. Here, I am making a performative claim to the space of the Prince's Bridge with the intention to resist and protest a neoliberal representation of the space and hopefully shift the public imaginary around this space...if only for a moment.

In the next iteration I am running the city. I wanted to run the city for the cause of Bloomerism. as a way to acknowledge these female dress reform campaigners of the past. Blooming Fast, wearing black and carrying a bloomer flag, wanted to literally carve out a silhouetted space for the women of the past. I wanted to have this character running not walking the city, as running in this congested space seemed like a subversive act. Running to me, harnesses a sense of power and freedom in a way that walking may not. And running, when not in running clothes interestingly becomes something completely different and somehow dangerous. This incursion became another retrospective performative recovering of space as I was running for those women of the past. The Fountain Flaneuse was a summer iteration that I created to playfully push the boundaries of public space. The incursions occurred at the Hochgurtel Fountain by Josef Hochgurtel, 1880 and the William Stanford Bluestone Fountain, 1870. These fountains built in Colonial times, were built to evoke a sense of grandeur. I wanted to put the female form into these spaces and I liked the idea of questioning the function of these fountains.

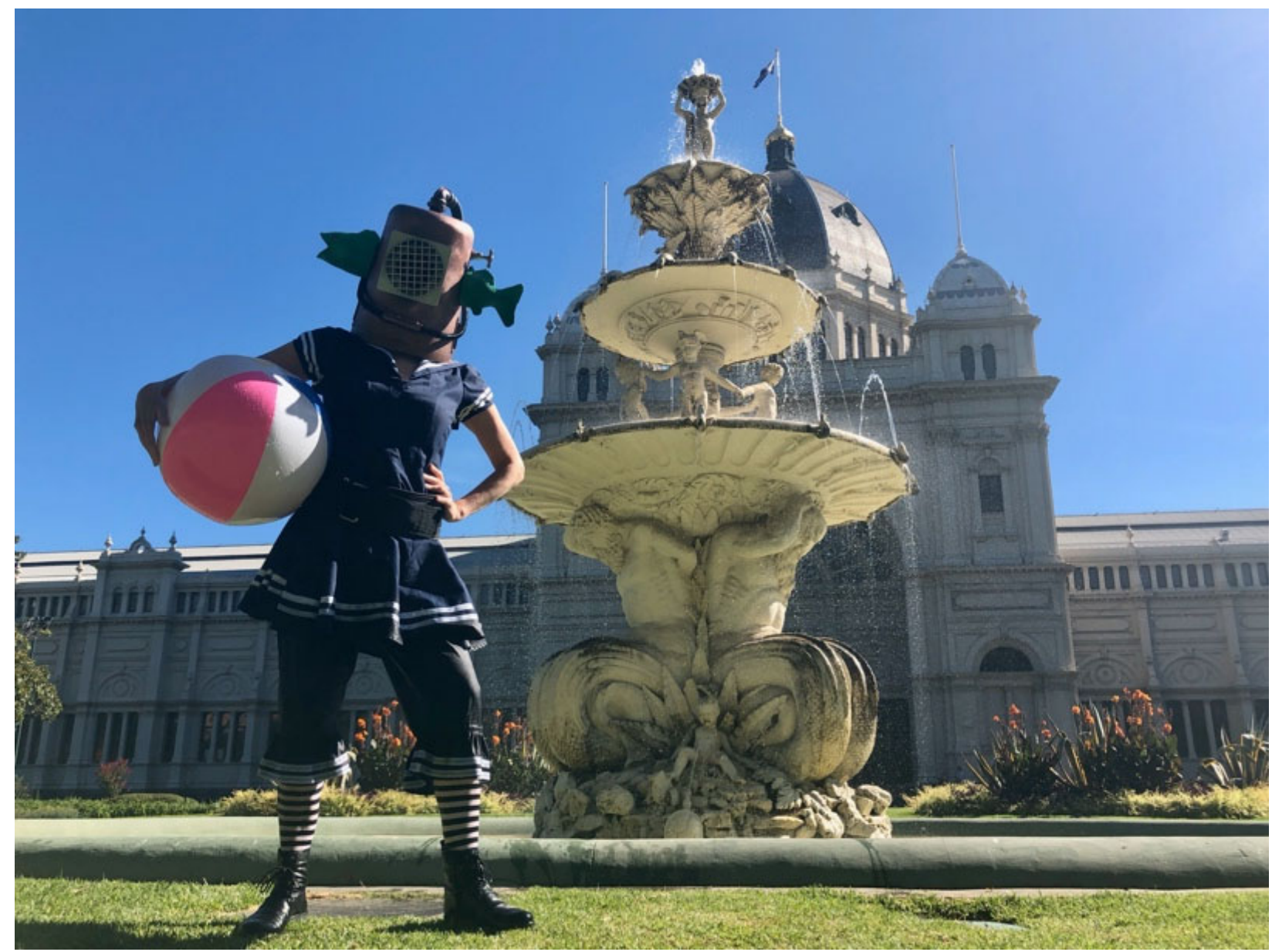

Figure 7. Fountain Flaneuse. Hochgurtel Fountain, Carlton Gardens. Photo by Jeremy Griffith. 
Why is the fountain a space for just looking when we endure 40 degree days of heat? Are sites of play in the city only for the young and in designated playgrounds? Where are sites of play in the city for adults? Sometimes children transgress the boundaries of the fountain but rarely adults. Why is this? What other boundaries of the city do we unconsciously adhere to? By using the fountains for play I am producing spaces of representation that oppose the official representations of space and thereby making a performative claim to recover the space.

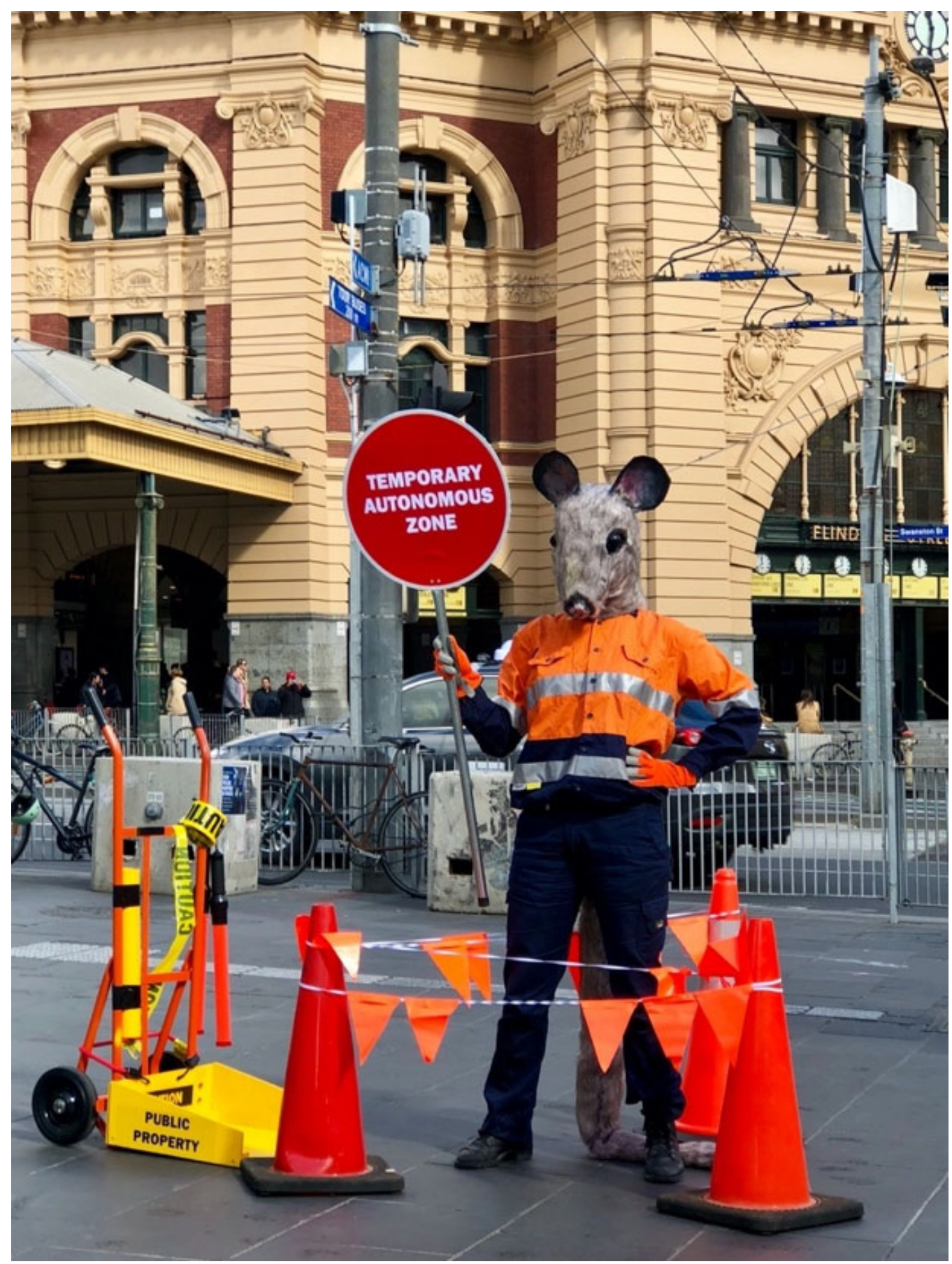

Figure 8. The Envoy of Mischief. Swanston St, Melbourne, 2018. Photo by Jeremy Griffith. 
My final character was created as a response to city public space becoming increasingly privatised (Sassan 2017). I created the rat character, The Envoy of Mischief, dressed in construction worker clothes with associated props. She was said to have appeared from the cracks in the city and having taught herself the language of the city, she is fluent in both construction and real estate. Rather than real estate though, she is selling a revolutionary dream, the Temporary Autonomous Zone (TAZ). It is an idea coined by Hakim Bey, an American anarchist author, based on the notion of the pirate utopias of the 18th century.

Bey describes the zone as,

an uprising which does not engage directly with the state, a guerrilla operation which liberates an area (of land, of time, of imagination ) and then dissolves itself to reform elsewhere/elsewhen, before the state can crush it (Bey 2003, p. 99).

This description sits eloquently with The Envoy's act of poetic terrorism in that the Rat creates these zones throughout the city then packs them away to move on to the next.

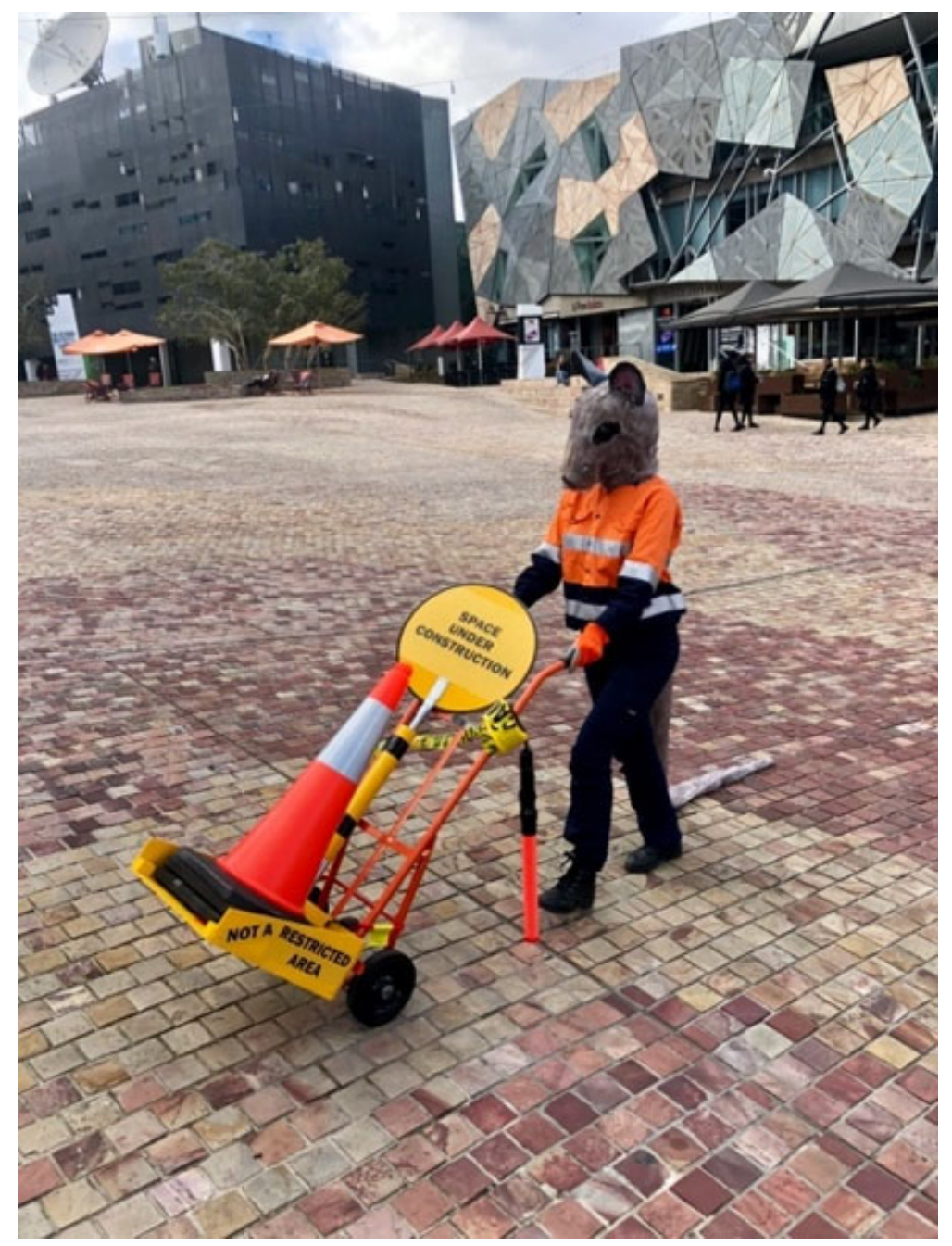

Figure 9. The Envoy of Mischief. Federation Square, Melbourne, 2018. Photo by Jeremy Griffith. 
The first site that the Envoy claimed was at Federation Square where at the time, an Apple store was threatening to encroach on this space. Among the other many zones secured was the lobby space of the Melbourne Stock Exchange where the rat was asked to leave by security and the steps of Victorian Parliament where the Police also asked her to leave. Both of these encounters were fairly benign yet they make visible the invisible boundaries of 'acceptable' use of public space. In the Rat's performative claim to space in these sites, the representations of space are resisted and could be said to be made more expansive in these moments. I also consider these interactions as disruptions to the consensual surface (Mouffe 2007). At these moments where authority steps in to remove the rat, the hegemonic powers within that space are revealed.

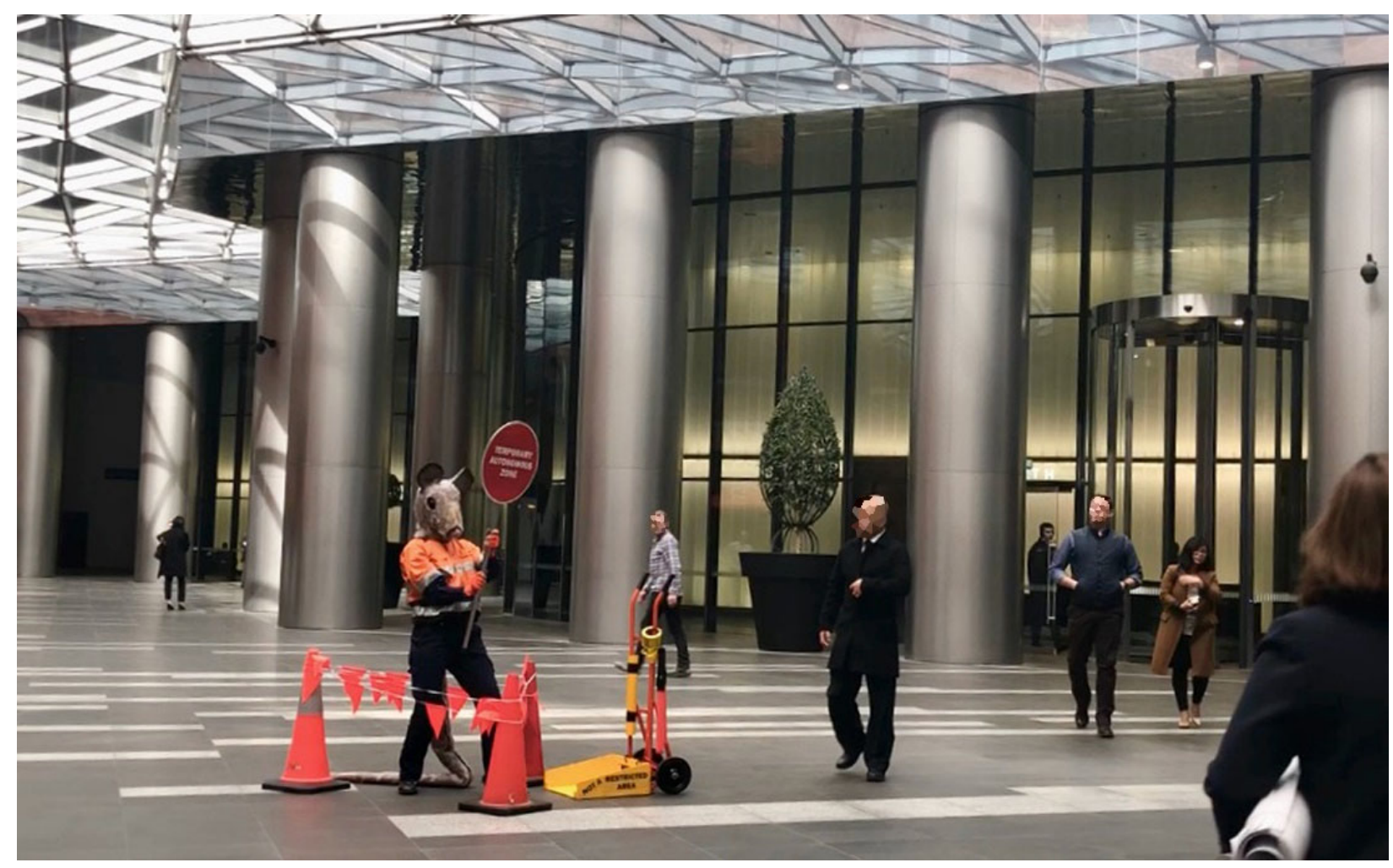

Figure 10. The Envoy of Mischief. Lobby of The Melbourne Stock Exchange, 2018. Photo by Jeremy Griffith.

Within both the notion of space as a dynamic and fluid entity (Lefebvre 1991) and the articulation of public space as a politically contested site (Mouffe 2007), there exists an opportunity for the citizen to foreground and reveal these notions by rupturing and recovering that space, if even for a moment in time. This gesture alone, has the potential to invite the public to question and re-look at public space with 'new eyes' and shift the public imaginary. As the Carnival existed not just as a form of agency for the everyday citizen but a reminder that agency was possible (Bakhtin 1984), my incursions hope to create and inspire mini revolutions of public city space. 
Play in Melbourne City

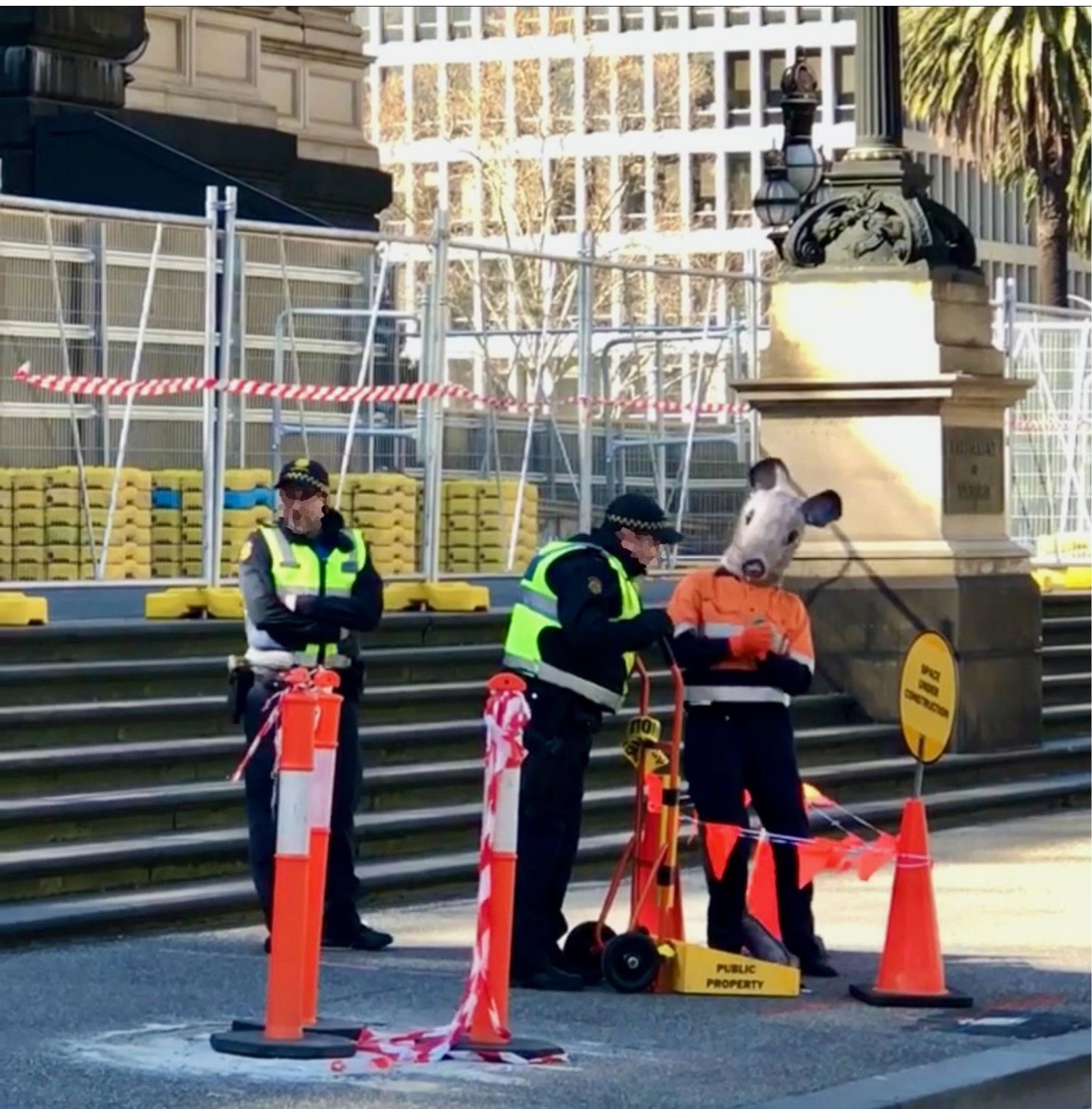

Figure II. The Envoy of Mischief. Steps of Victorian State Parliament, 2018. Photo by Jeremy Griffith

366 | The Journal of Public Space, 5(4), 2020 | ISSN 2206-9658

City Space Architecture / UN-Habitat 


\section{References}

Alys, F. (2004). The Nightwatch. online video. Copyright Francis Alys. Available at: http://francisalys.com/the-nightwatch/

Bakhtin, M.M., (1984). Rabelais and His World, Bloomington, Ind.: Indiana University Press.

Bey, H. (2003). T.A.Z. The Temporary Autonomous Zone, ontological Anarchy, Poetic Terrorism. (2nd Edition with new preface). Automedia, NY.

Hochgurtel, J. ( 1880 ). The Hochgurtel Fountain, portland cement fountain, Carlton Gardens, Melbourne

Incursion. (2020) Cambridge Online Dictionary. Cambridge University Press. Definition available at: https://dictionary.cambridge.org/dictionary/english/incursion

Lefebvre, H, Author, Nicholson-Smith, D, and Lefebvre, H.(I99I). The Production of Space. Blackwell,Oxford, UK. Available at: https://monoskop.org/images/7/75/Lefebvre_Henri_The_Production_of_Space.pdf

Mouffe, Chantal. (2007). "Artistic Activism and Agonistic Spaces," in: Art \& Research: A Journal of Ideas, Contexts, and Methods, I/2, Summer 2007. Available at: http://www.artandresearch.org.uk/vln2/mouffe.html

Sassen, S. (2017). 'The City: A Collective Good?' Brown Journal of World Affairs 2017 Spring /Summer, Volume xxiii, Issue ii. Availabe at: http://saskiasassen.com/PDFs/BrownJn12017\%20City\%20Colectv\%20good\%20copy.pdf Stanford, W. (I870). William Stanford Bluestone Fountain. Gorden Reserve, Melbourne. 